\title{
Democracies and the Power to Revoke Citizenship
}

\author{
Patti Tamara Lenard*
}

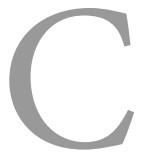

itizenship status is meant to be secure, that is, inviolable. Recently, however, several democratic states have adopted or are considering adopting laws that allow them the power to revoke citizenship. This claimed right forces us to consider whether citizenship can be treated as a "conditional" status, in particular whether it can be treated as conditional on the right sort of behavior. Those who defend such a view argue that citizenship is a privilege rather than a right, and thus in principle is revocable. Participating in a foreign state's military, treason, spying, or committing acts that otherwise threaten the national security of one's state may all warrant revocation. This article assesses the justifications given for the claimed power to revoke citizenship in democratic states and concludes that, ultimately, such a power is incompatible with democracy.

I begin with a brief account of the claims given by contemporary democratic states for the "right to revoke." Democratic citizenship is today commonly understood to be egalitarian, that is, it protects an equal basic package of rights for all citizens; and to be "the highest and most secure legal status," that is, it is meant to be secure from unilateral withdrawal by the state. ${ }^{1}$ Formally, many democratic states have revocation laws on the books, but most of these have long been in disuse. Although I argue in this article that all revocation laws are inconsistent with democratic citizenship, I focus on the recent surge in proposed and implemented revocation laws, which are justified as essential to protecting national security.

In the second section I outline three reasons to object to revocation laws. First, revocation laws discriminate between citizens based on their citizenship status. Second, since they single out those who are eligible for revocation, they apply

\footnotetext{
${ }^{\star}$ I would like to thank the audiences at the Carleton University Philosophy Department Colloquium, the Queens University Political Studies Speaker Series, and the Binghamton University Philosophy Department Colloquium, as well as the anonymous reviewers for this journal, for comments on an earlier version of this article.
}

Ethics \& International Affairs, 30, no. 1 (2016), pp. 73-91. (C) 2016 Carnegie Council for Ethics in International Affairs doi:10.1017/So892679415000635 
unequal penalties for the same crime. Third, they are insufficiently justified, in general, but also particularly to those who may be subject to them, because they are not adequately connected to the policy goal they are said to fulfill. I conclude with some brief observations concerning the ways in which revocation permits states to abrogate their shared responsibility for protecting the global community from dangerous individuals.

It is worth acknowledging at the outset that the legitimacy of sovereign states rests in part on their ability to protect the safety and security of their citizens. Indeed, security is foundational to any functional democratic state, for without it citizens will not be free to go about their daily lives. ${ }^{2}$ Therefore, when states argue that a particular policy is essential to protect the security of citizens, they are making a profound claim about the importance of that policy. Since 9/11 states have been particularly concerned about protecting citizens from acts of terrorism, and they have proposed that certain rights and protections normally owed to citizens can be undermined in response to this apparent threat. The power to revoke is defined in precisely these terms: for example, as Shai Lavi writes, "deprivation of citizenship is . . the necessary precondition of being able to deny unwanted individuals - that is, those who are seen as posing a risk to public security and safety"-the protection that citizenship status entails. ${ }^{3}$ Critics of this "securitization" move have argued that states are far too quick to claim "security" as a justification for rights-restricting policies, and that the long-term consequence of acquiescing to these justifications is the "normalization" of the exceptional. ${ }^{4}$ This article considers the claimed power of states to revoke citizenship within the context of the larger debate about the ways in which the importance of protecting security appears to justify restricting citizens' rights. ${ }^{5}$

\section{Democratic States and the History of Citizenship Revocation Powers}

Historically, states, including democratic ones, have protected their right to revoke citizenship. They have been amply supported by liberal political theorists (including Immanuel Kant and Benjamin Constant) who, in the name of state sovereignty, have been willing to endorse "the legitimacy of the punishment [of withdrawal of citizenship] as long as it [is] not used arbitrarily." ${ }^{6}$ Furthermore, at least historically, while citizenship in democratic states did imply access to certain formal protections by the state, it did not necessarily translate into a strong commitment 
to equality; democratic states regularly recognized the citizenship of women and of propertyless men, for example, while denying that they were entitled to equal rights, such as the right to vote. More recently, however, the expulsion of Jews from Nazi Germany following their denationalization generated a consensus among democratic states that there is something profoundly objectionableindeed, profoundly undemocratic-about the power of a state to revoke citizenship unilaterally. As Audrey Macklin observes, citizenship is a kind of "meta-right" because its absence "places all rights in the balance." It is the source from which all additional rights flow, and is itself essential to protecting these rights. For the most part, citizenship does not create rights deserving of protection; rather, it formally designates the entity responsible for protecting these rights. ${ }^{8}$

Reflecting this consensus, the United Nations Convention on the Reduction of Statelessness was enacted in the early 1960s. The Convention aimed to respond to the far too extensive discretion of states that enabled them to denationalize citizens during World War II. Among its goals was to recognize the right to security of residence as a basic human right, that is, the right of individuals to know that they are secure in where they build their homes and establish their communities. To be stateless is to be tremendously vulnerable, since in addition to having nowhere to securely build one's life, there is no state responsible for protecting one's rights. The Convention thus highlights and bans the "unjust and cruel" wrong of rendering an individual stateless via denationalization. However, so long as the affected individual would not thereby become stateless, it permits a range of revocation laws. The Convention thus puts a limit on (but does not ban outright) states' discretion to control their membership. Among the signatories to this Convention (sixty-eight states have signed or ratified it), those states that have sought to protect or implement revocation laws have generally recognized the commitment to which they are bound, and have written their laws to include a clause acknowledging that revocation is permitted only in cases where statelessness is not the result.

The view that citizenship is a near perfectly secure status is now implicit in most theories of democratic citizenship. For example, as Ben Herzog notes, the "revocation of citizenship is [now] associated with totalitarian or oppressive regimes" and not democratic ones. ${ }^{9}$ Similarly, after observing that historically many states practiced banishment and expulsion, Joseph Carens suggests that contemporary democracies eschew these practices because they are so fundamentally harmful that they are "no longer considered an acceptable form of punishment for citizens, 
even heinous criminals." Carens concludes that "forced exile of citizens is regarded as a violation of human rights." ${ }^{11}$ Thus, while it remains true that most European states have revocation laws on the books (fourteen of these permit revocation for "seriously prejudicial behavior"), until very recently such laws were effectively in disuse. ${ }^{12}$

This post-World War II consensus may be breaking down, however, as states start adopting new revocation laws or reinvigorating abandoned ones, allegedly to support the fight against terrorism and to protect against national security threats. For example, as of 2010 Dutch law permits the revocation of citizenship of those who are convicted of compromising national security. Defending this law, the Dutch government argued that "in cases where the government decides to withdraw nationality, the irrevocably convicted person has demonstrated that he has renounced his bond with the Kingdom and has taken the risk of losing his Dutch nationality into account." ${ }^{13}$ In the summer of 2015 the Canadian government passed the Strengthening Canadian Citizenship Act, one provision of which permits the revocation of citizenship of dual citizens convicted of crimes that threaten Canadian national security, including terrorism and spying. ${ }^{14}$ In defending the law, then Canadian Minister of Citizenship and Immigration Chris Alexander said: "Dual citizens who are convicted of serious crimes such as terrorism and treason should not have the privilege of Canadian citizenship."15

In the United States the power to revoke citizenship has effectively been dismantled by several judgments of the Supreme Court, which has declared the practice unconstitutional except where it can be proved that the criminal, by her actions, intended to relinquish her American citizenship. ${ }^{16}$ While such an intent may be difficult to prove, the provision has been deployed in defense of revocation laws by their proponents. In 2010, for example, then U.S. Senator Scott Brown, who cosponsored a bill that would have permitted revoking the citizenship of supporters of terrorist groups, argued that "individuals who pick up arms [against the United States] . . . have effectively denounced their citizenship, and this legislation simply memorializes that effort. So, somebody who wants to burn their passport, well, let's help them along." ${ }^{\prime 17}$ Norway is currently considering whether to implement revocation laws, and Norwegian Minister of Children and Equality Solveig Horne has vowed to "turn over every stone to find the necessary measures to prevent radicalization and extremism" and has declared that "any citizen causing serious damage to vital government interests or who has volunteered to serve in foreign military services" should be considered subject to possible revocation. ${ }^{18}$ 
Former Australian Prime Minister Tony Abbott signaled his government's intention to join this trend, declaring that "we will be legislating within a few weeks to strip dual citizens involved in terrorism of their Australian citizenship." (As of late November 2015, news reports suggest that the Australian Parliament is set to adopt a revocation law by the end of the year. $)^{19}$ And, as has been widely reported, immediately following the November terrorist attacks in Paris, French President François Hollande announced his intention to demand changes to France's Constitution to permit the revocation of citizenship of dual nationals born in France (rather than of only those who are naturalized French citizens). ${ }^{20}$

The right to revoke has progressed most significantly in the United Kingdom, where laws long abandoned but still formally on the books are being reactivated and deployed. Matthew Gibney reports that only ten British citizens were denationalized between 1949 and 1973, and no one suffered this fate between 1973 and $2001 .^{21}$ Since then, however, the government has signaled its intention to redeploy its power to revoke. Citing the importance of enhancing the tools available to the government to fight terrorism, in 2002 the United Kingdom adopted legislation permitting revocation in cases where the secretary of state believes that "an individual's holding citizenship is 'seriously prejudicial to the vital interests' of the U.K." 22 In 2006 the "vital interests" criterion was expanded, this time to allow the secretary of state to revoke citizenship in cases where an individual's holding British citizenship was "not conducive to the public good," thus allowing public officials even more discretion in deciding to withdraw citizenship. ${ }^{23}$ As a result, one recent estimate suggests that since 2006 twenty-seven British citizens have been denationalized." ${ }^{24}$ Also as of 2006, the United Kingdom has permitted its own revocation laws to apply even where doing so would render an individual stateless, a law that violates the UN Convention on the Reduction of Statelessness, to which the United Kingdom is a signatory. ${ }^{25}$

Revocation laws take a number of forms, which makes it challenging to consider their merits and demerits as a collective; I am mainly concerned here with states that permit revocation as a form of punishment for, or deterrence from, terrorist activities or other crimes deemed to threaten a state's national security, including in many cases participation in a foreign army or conflict. Most states permit voluntary renunciation of citizenship, under some conditions. Most also permit revocation in cases where citizenship has been attained fraudulently; in many such cases, fraudulently acquired citizenship can be revoked even where it would produce statelessness (France and Luxembourg appear to be two exceptions to this 
rule in Europe). ${ }^{26}$ Many states revoke citizenship, in some cases automatically, for those citizens who voluntarily naturalize elsewhere; and many also allow for revocation (under a variety of conditions) in cases of permanent residence abroad. Further, some states permit the revocation of citizenship of minors in cases where their parents' citizenship is revoked or renounced. ${ }^{27}$

In the majority of cases where revocation can be lawfully applied as a punishment or as a deterrent for certain activities-most relevantly for this article, for the commission or anticipated commission of acts deemed to be threats to national security-it is permitted only where statelessness would not be the result, as in the Dutch and Canadian cases. Among recently proposed and implemented revocation laws, only the United Kingdom permits revocation even where it will produce statelessness. In practice, the imperative to avoid statelessness means that revocation laws generally differentiate between dual citizens, who can be denationalized without being rendered stateless, and single nationality citizens, who would be stateless if their denationalization were permitted. In these latter cases, where differentiation between dual and single nationality citizens is permitted by law, some states differentiate further between dual citizens who have naturalized into a second citizenship (by migrating) and those who have been born into dual citizenship (for example, children who are entitled to the citizenships of two parents of different nationality). In some cases, revocation is permitted only where courts of law have convicted an individual of a revocation-worthy offense, as is the case in Canada. In others, revocation is permitted by ministerial discretion alone, as is the case in the United Kingdom.

With the exception of those statutes that permit revocation in cases of fraud, ${ }^{28}$ I shall criticize all permutations of revocation laws. Some permutations of these laws are subject to only some of the objections I raise below, but none is immune from all of them.

\section{Three Arguments against Revocation in Democratic STATES}

Given that the post-World War II consensus that citizenship is nearly inviolable may be breaking down, it is crucial to articulate clearly the reasons we ought to continue to uphold this ideal. My argument is that the concept of citizenship as a revocable status is incompatible with democratic citizenship, for three main reasons. First, revocation laws often treat citizens unequally, by subjecting only some to the threat of revocation on the basis of national origin or identity. Second, 
revocation laws treat citizens unequally by issuing different punishments for the same crime, again on the basis of national origin or identity. And third, the reasons offered to support the power to revoke are inadequate to justify the policy's profoundly coercive impact on some citizens.

\section{Objection 1: Subjecting Only Some to the Threat of Revocation on the Basis of National Origin or Identity}

Democratic states are founded on a commitment to equality. Perhaps the most general way to express this commitment is by acknowledging that democracies aim to protect and respect the equal moral worth of all of their members. This foundational commitment is fleshed out in a range of ways. For example, Thomas Christiano proposes that democratic equality be understood in terms of interest: "The basic institutions of [democratic] society are charged with the task of advancing the interests of all members of society equally." ${ }^{29}$ Michael Saward's account of equality in democratic states instead focuses on the ways in which citizens of these states can have equal voice in decision-making procedures. ${ }^{30}$ Additionally, democratic constitutions typically list the distinct ways in which citizens may not be treated unequally: on the basis of sex or sexuality, race, religion, or national origin, among many other categories. It is of course well observed that protecting equality, however understood, does not necessarily require equal treatment of all individuals; in many cases, achieving the goals set by a commitment to equality will require differential treatment. ${ }^{31}$ To offer an obvious example, equality may demand, as it does in the case of some individuals with physical disabilities, the provision of additional resources so that they too can achieve equal mobility.

It is not essential here that we adjudicate among these distinctive ways of grounding and instantiating democratic equality; on whatever understanding of equality one chooses to endorse, I believe the power of the state to revoke citizenship represents a violation of this commitment. In particular, democratic equality is inconsistent with the power to revoke, for two reasons, which I consider in this section and the next, respectively: (a) the power to revoke provides unequal access to security of residence, discriminating as it does against individuals on the basis of their national origin; and (b) the power to revoke subjects individuals guilty of the same crime to different, that is, unequal punishments.

Because of the imperative to avoid statelessness, most revocation laws are written so that the only individuals subject to revocation are dual citizens. In some cases, proposed or actual revocation laws target only dual naturalized citizens. 
According to a recent study of citizenship loss in thirty-three European countries, eight countries permit the revocation of citizenship for "seriously prejudicial behaviour," but only for naturalized citizens. ${ }^{32}$ Restricting revocation laws to dual citizens serves a rhetorical purpose in democratic states, especially diverse ones, that should be troubling to those concerned with protecting social cohesion, as "the singling out of the naturalized has historically been linked to (often racist) anxiety about the loyalty of citizens born outside the state." ${ }^{33}$ Particularly during times of war, states have worried that dual citizens are inclined toward disloyalty; indeed, historically "states regarded dual citizenship as a potential catalyst for treason, espionage, and other subversive activities." 34 As a result, for decades the international consensus was that dual citizenship ought to be avoided.

Over the last thirty years, however, the global consensus has shifted toward an acceptance of dual citizenship. There are many different factors explaining this shift. The increasing acknowledgement of dual citizenship does not flow from an acceptance that individuals possess a right to be citizens of two countriesdual citizenship is not seen as a right in and of itself. Rather, acceptance stems from the general acknowledgement of other rights, for example, the right of women to maintain rather than automatically lose their citizenship when they marry across national boundaries and the right to rapid naturalization to facilitate the protection of their families, as well as the right of both parents to pass their citizenship on to their children. ${ }^{35}$ More generally, however, this consensus is based simply on the recognized desire of both expatriates and their states of origin to sustain formal legal connections, even where expatriates naturalize in a second state. ${ }^{36}$ The 1997 European Convention on Nationality reflects this consensus and no longer discourages states from recognizing dual nationality, as its predecessor had done; it "also provides for explicit acceptance when children acquire dual citizenship by birth and when renunciation or loss is not possible or cannot be reasonably required." 37 In adopting these provisions, the Convention can be read as recognizing that dual nationality should no longer be understood as an indication of disloyalty. As a result, European states are increasingly permitting and in some cases even encouraging dual citizenship.

Nonetheless, recent public debate concerning revocation laws suggests that the loyalty of migrants is sufficiently suspect such that, where they choose to maintain dual nationalities, they ought to be subject to laws permitting the revocation of their acquired citizenship (even where they have met increasingly demanding naturalization requirements). For example, in 2010 then Secretary of State Hillary Clinton 
defended the aforementioned legislation empowering the State Department to revoke the citizenship of terrorism suspects, arguing that "United States citizenship is a privilege ... not a right. People who are serving foreign powers-or in this case, foreign terrorists-are clearly in violation, in my personal opinion, of that oath which they swore when they became citizens." ${ }^{8}$ While it is true that a large number of dual citizens are migrants who have naturalized into a second nationality without being required to give up their nationality of birth, many dual citizens are in fact native-born. For example, as of 2011 at least 20 percent of all dual citizens in Canada were born there. The public debate, however, propagates the widespread assumption that dual citizens are migrants who have naturalized, and thus are from "elsewhere," rather than citizens by birth. ${ }^{39}$ Revocation laws may therefore serve to "fuel a sense of secondclass citizenship among the affected communities and erode their feelings of social solidarity" with the wider political community. ${ }^{40}$ In so doing, they permit rather than suppress the view that certain citizens are less likely to be loyal and may prove damaging to democratic inclusion.

Where the law draws a distinction between two categories of citizens-those whose status is acquired by birth and those whose status is acquired via naturalization-it is straightforwardly discriminatory. ${ }^{41}$ Many states recognize that legal distinctions of this kind, between naturalized and non-naturalized citizens, generate an unjust inequality between citizens. To address this inequality, revocation laws can be written so as to subject all dual citizens to the risk of revocation, as is the case in Canada. Advocates of this approach suggest that in principle such a law is nondiscriminatory, since any citizen can be a dual citizen-whether because of naturalization or because of inheritance. Such advocates also typically suggest that by keeping dual citizenship individuals are advantaged in relation to those who possess only a single citizenship. ${ }^{42}$ It is thereby implied that revocation laws somehow restore the balance between the benefits and burdens shouldered by dual and single nationality citizens. Yet while such a law resolves one inequalitybetween naturalized and non-naturalized dual citizens-it broadens the inequality between single nationality citizens and all dual citizens.

Objection 2: Subjecting Some Citizens to More Significant Punishment than Others for the Same Crime

The rule of law protects the equality of citizens by preventing the arbitrary exercise of power. This is what Benjamin Constant had in mind when he wrote that the rule of law enshrines "the right to be subjected only to the laws, and to be neither 
arrested, detained, put to death, or maltreated in any way by the arbitrary will of one or more individuals." 43 Importantly, these laws protect both innocent and criminal citizens. Citizenship revocation laws, however, often violate the due process rights that guarantee that all legal and court proceedings will treat those subject to them fairly, in accordance with the rule of law. Moreover, even if due process rights were adequately protected in such cases, by subjecting some criminal citizens to harsher penalties than others, revocation ultimately violates the commitment to equality of punishment in democratic states. Let me elaborate on each of these claims.

One of the dangers posed by the power to revoke citizenship is its manner of proposed and actual implementation, which permits extensive discretion to those charged with implementing it. For example, as noted above, U.K. law permits revocation where individuals commit acts that are not consistent with the public interest, but this vague definition allows for dangerously broad application. Additionally, in both the United Kingdom and Canada the decision to revoke is made by immigration officials, rather than administrators in a court of law (although in Canada revocation is currently permitted only after a court has convicted an individual of a revocation-worthy crime); that is, individuals with little or no legal experience are entitled to exact punishment for criminal acts. The discretion offered to these public officials, which, as in the United Kingdom, permits revocation without allowing the individual in question to hear or refute evidence in a court of law, violates the due process rights possessed by all citizens of a democratic state, as do laws that permit revocation on the basis of having been prosecuted for a crime in another country. This latter stipulation, present for example in the previously discussed 2015 Canadian law, permits the revocation of Canadian citizenship in the event that a Canadian is convicted of a revocationworthy crime abroad. I believe this is a violation of the affected person's rights of due process as a Canadian. ${ }^{44}$ Moreover, due process laws in democratic states not only protect the rights of the guilty, they also protect the innocent from baseless persecution and charges of guilt by association. Taken together, these stipulations amount to offering far too vast a discretion to public officials; the opportunity for abuse is too high to countenance where the penalty is so severe. Thus, as they are proposed and actually implemented, revocation laws violate due process rights to which democratic states are committed under the rule of law.

But perhaps, in principle, a revocation law can avoid these procedural challenges. For example, in the Netherlands a 2013 amendment to the 2010 revocation law 
made revocation automatic for dual citizens following conviction of certain crimes, thus removing the discretion of administrative personnel altogether. Yet there remains a second democratic egalitarian reason to reject such a power. ${ }^{45}$ In particular, it produces an inequality between various citizens with respect to the punishment they can expect to receive for having committed a criminal offense. Indeed, when states aim to establish fair and just punishments for crimes, one key question is whether all individuals responsible for the crime are subject to the same punishment. For example, one injustice perpetrated in the American antebellum South was the way in which punishments were unfairly meted out to white and black Americans; the latter could, sometimes as a matter of codified law and other times as a matter of practice, expect much harsher punishments for the same crime. By loose analogy, where dual citizens and single nationality citizens commit the same crime, only the former can be subject to citizenship revocation; revocation is imposed on top of a sentence that is, at least ideally, already agreeed to be fair. ${ }^{46}$

Still, one might respond that the criminal justice system in democratic states frequently imposes different punishments for the same crime. The mentally ill and the developmentally disabled are often subject to less severe penalties in criminal trials than their co-nationals, but in these cases there are mitigating circumstances that explain the distinct punishment. In cases where only some individuals are subject to revocation laws, the only distinguishing feature such individuals have is the possession of a second nationality. At first glance, the possession of dual citizenship may appear to be a relevant distinguishing feature. One might believe, for example, that the carrying out of crimes that threaten one's own state's national security (or even the intention to carry out such crimes) is adequate evidence that one no longer desires to be part of that national community. ${ }^{47}$ Especially in times when fear of national security threats is heightened, it is common to worry that dual citizens (and foreigners) are more likely than singlenationality citizens to carry out crimes that threaten the state. In such times, states may allow a population to believe that there is a clear connection between revocation policies and such crimes, justifying their differential treatment of dual citizens. We ought to resist this conclusion, however. Such reasoning is troubling because it assumes a connection between citizenship status and an alleged propensity to carry out crimes, which is then used to justify differential punishment for the same crimes.

Revocation is also problematic as a punishment due to the profound unpredictability of its consequences. ${ }^{48}$ Recall that the commitment to the rule of law stems 
in part from the demand to avoid arbitrariness; unpredictability is one form that such arbitrariness can take. As in the cases of the laws canvassed above, an individual who is charged (or accused or even in some cases simply suspected) of criminal activity that carries revocation as a penalty can almost immediately be deported to her country of alternative citizenship. There, it is possible that rather than being incarcerated for having committed (or threatening to commit) a grievous harm, this person will live in freedom. Or this individual may find herself without adequate state protection, a danger in particular if she is deported to a weak or failing state. Consider two recent cases in which the United Kingdom revoked the citizenship of British citizens who were subsequently killed by American drones in Somalia. ${ }^{49}$ In these cases, there is no confirmed direct connection between their denationalization and their deaths, but there is a real worry that their execution might have been facilitated by the fact that U.S. commanders were aware that they would not be killing citizens of an ally. The revocation of citizenship can thus result in both illegitimately lenient and illegitimately severe punishments. ${ }^{50}$

Objection 3: Inadequate Evidence to Justify the Policy's Profoundly Coercive Impact on Some Citizens

In democratic theory, citizens are considered entitled to justifications for the policies their leaders intend to pursue, in particular where these laws are likely to have a coercive impact on them. As Michael Blake has observed, although coercion is an essential feature of collective democratic life, any coercion exercised on citizens must be justified. ${ }^{51}$ What makes the coercion acceptable in a democratic state is that citizens who are subject to that coercive authority have access to the justifications for this authority as well as the opportunity to refute these justifications where they are believed to be inadequate. There is much disagreement among political theorists about how to justify the adoption of public policies that can be predicted to impose a more significant burden on some citizens than others. Nevertheless, there is widespread agreement that, in order to be justified, they must meet at least three criteria: first, there must be a clear connection between the policy objective being pursued and the means proposed to meet it; second, the proposed policy must be recognizably better than existing policies in some respect; and, third, assuming these criteria are met, the proposed policy must be shown to be the least burdensome mechanism by which the goal can be achieved. 
The first criterion requires that there is a clear connection between the stated objective of a policy and the means proposed to achieve it; in particular, the means proposed must be plausibly understood as able to deliver the objective at stake. The broad policy objective vis-à-vis citizenship revocation is, of course, fighting terror, and revocation is presented as contributing to meeting this objective in two ways: it will deter some individuals from carrying out terrorist actions, since losing one's citizenship will be taken to be too high a price to pay; and it will permit a government to refuse re-entry to individuals with nefarious intent or to deport them if they manage to regain access to that territory. Let me consider each of these reasons in turn.

Revocation laws are sometimes defended for their contribution to deterring terrorist activity. The logic is, roughly, that those who might otherwise consider committing heinous crimes may be dissuaded by the threat of having something valuable taken from them. This reasoning is in evidence in Canada and Australia. In defending Canada's 2015 revocation law, the Minister of Citizenship and Immigration explained that "Everyone should celebrate the fact that [the procedures by which revocation will be implemented] will constitute a very profound deterrent, not just to younger generations, but to all Canadians, and a reminder that allegiance and loyalty to this country require that these grave crimes be avoided at all costs." 52 Similarly, in June 2015 the Australian government presented an "Exploratory Memorandum" to the House of Commons explicitly listing deterrence as one of its justifications for pursuing citizenship revocation in cases of individuals who threaten national security. ${ }^{53}$ No one denies that deterring criminal activity, including terrorism, is extremely important. Thus, no one denies the importance of directing resources, and allocating certain powers, to those government departments charged with protecting citizens from violent criminal activities so that they are able to do their job adequately. One should be wary, however, of the suggestion that those dual citizens who might otherwise commit acts of terror and violence will be deterred from doing so simply because they are at risk of losing one of their citizenships. ${ }^{54}$ In perhaps the only analogous case of as severe a punishment-execution by the state-evidence suggests that it has only a minimal deterrence effect, and the issue is a matter of ongoing debate. ${ }^{55}$

If the power to revoke is not adequately justified for its ability to deter terrorist actions, can it be justified for its contribution to protecting the security of citizens? By deporting or preventing the re-entry of individuals who have become radicalized abroad, and who in so doing have developed or honed the skills necessary to 
cause widespread damage, governments may thereby exclude dangerous individuals from their territory. Citizens are thus made more secure. However, while the number of individuals leaving democratic states to fight in foreign wars is unambiguously growing, and even given the fact that the terrorist attacks in Paris were carried out by individuals who appear to have travelled extensively between Europe and the Middle East, there is not yet significant evidence to suggest that these individuals often return with an intention to harm their country of citizenship. ${ }^{56}$ The same is true historically: in general, so-called foreign fighters have not returned to their countries of citizenship with the intention of deploying skills learned abroad to cause harm. ${ }^{57}$

In order to justify a policy that threatens some citizens with severe harm, there must be reason to believe that (a) existing policies are inadequate to pursue the relevant objectives and (b) that the chosen policy is the least harmful way in which the relevant objectives can be met. Even where a political community agrees that a particular goal is worthwhile, and that some citizens' interests will have to be sacrificed in order to achieve this goal, democratic states are obligated by their commitment to equal citizenship to minimize the sacrifice asked of those who will be disadvantaged. The burden on policymakers is especially high in cases where the rights of some individuals are at risk of being sacrificed, as in the case of revocation.

Yet here, as well, to the extent that the state provides evidence in defense of the power to revoke, it does not meet these criteria. It is certainly the case that many democratic states have already suffered acts of terrorism, and many more are certainly at risk of being victimized by terrorist actions. It would be a mistake, however, to presume that what is under discussion is the ability of a state to fight terror at all; nearly all states have tremendous ability to fight terror. The question is whether the ability to revoke citizenship will aid significantly in doing so, since it is a power that burdens some citizens in substantial ways. Thus, where the government demands the right to saddle a small subset of citizens with a substantial burden-the risk of having their citizenship revoked-it must offer reasons to believe that the power is essential to fight terrorism effectively.

Is there any reason to believe that existing policies are inadequate to protect national security? It is of course worth adopting new policies to achieve desirable goals, if they are more efficient at achieving them or can do so in more costeffective ways. First, though, citizens are entitled to understand why the existing suite of powers-which permits not only the prosecution of criminals (including 
terrorists) via the standard criminal justice system but also provides wide-ranging powers to governments to protect citizens against terrorism-is inadequate. They are equally entitled to an explanation of the significant difference the right to revoke will make in fighting terror. Fundamentally, it has not been made clear that the usual set of judicially applied sanctions (for example, imprisonment, rehabilitation, parole, or monitoring) is insufficient to punish and deter the bad actors targeted by revocation policies. If the state believes that certain crimes are underpunished or underdeterred at present, it can increase the associated prison terms, monitoring conditions, or parole durations. New powers, like the power to revoke, ought to be adopted only when they are more efficient at achieving goals or can do so in more cost-effective ways than the status quo. Thus, before acceding to claims that the power to revoke will improve a state's security capabilities, an account of why existing punishments within the criminal justice system are inadequate, or cannot be made adequate, is required. It is also worth noting that a significant number of individuals who are at risk of having their citizenship revoked for having committed terrorist actions abroad have been captured upon their return to their country of citizenship; in other words, these individuals are already in jail, often for indefinite periods of time, and thus it is not clear that additional security can be produced by denationalizing or deporting them-often, as would be the case, to states with less robust criminal justice systems.

These requirements - that in a democratic state the policy goal should be connected to the means adopted to achieve it; that the proposed means must be plausibly thought to be better (if not demonstrably better) than existing policies at achieving it; and that (if plausibly or demonstrably better) they must also plausibly (or demonstrably) be the least burdensome in particular to those who are likely to be affected by them-must be met in order to justify the coercion to which citizens in democratic states are subject. Absent such evidence, the power to revoke cannot be justified in democratic states.

\section{Conclusion}

The global community shares a collective duty to respond to the threats posed by terrorist activity, which often crosses borders. To highlight the importance of a coordinated and global response, the UN Security Council has issued multiple directives, indicating to states their shared responsibility to fight global terrorism. Citizenship revocation laws appear to violate duties implied by this shared 
commitment. States are generally responsible for issuing punishment to citizens and those on their territory who cause grievous harm of the kind that worries advocates of citizenship revocation. Thus, states that choose to revoke citizenship are effectively offloading responsibility for individuals they have deemed dangerous onto states that are often less able and willing to ensure that they are prevented from committing harm globally. By refusing to punish dangerous individuals, or by permitting them to remain largely unpunished for allegedly grievous crimes, the revoking state is also refusing to uphold its obligations to fight global terrorism.

One of the main arguments of this article has been that recent revocation laws create "second-class citizens" by opening a fundamental inequality between citizens who possess one nationality and those who possess two. In opening this fundamental inequality, and by rendering the citizenship of some citizens less secure, the power to revoke is incompatible with modern democratic citizenship. Nothing in this article should be taken to suggest that the state should be denied the powers it needs to protect its citizens. Rather, I have argued that in singling out either naturalized citizens or dual citizens for additional scrutiny, in subjecting these citizens to additional punishment in cases of grievously harmful crimes, and in failing to provide evidence that the right to revoke will achieve the policy objectives by which it is justified, the power to revoke is inconsistent with the commitments implied by modern understandings of democratic citizenship. Revocation laws therefore have no place in democratic states.

\section{NOTES}

${ }^{1}$ Audrey Macklin, "Citizenship Revocation, the Privilege to Have Rights and the Production of the Alien," Queen's Law Journal 40, no. 1 (2014), p. 4.

${ }^{2}$ Henry Shue, Basic Rights: Subsistence, Affluence, and U.S. Foreign Policy, 2nd ed. (Princeton, N.J.: Princeton University Press, 1996).

${ }^{3}$ Shai Lavi, "Punishment and the Revocation of Citizenship in the United Kingdom, United States, and Israel," New Criminal Law Review: An International and Interdisciplinary Journal 13, no. 2 (2010), p. 409.

${ }^{4}$ For one example of this kind of critique, see Michael C. Williams, "Securitization and the Liberalism of Fear," Security Dialogue 42, no. 4-5 (2011).

${ }^{5}$ See, for example, Glen Newey, "Liberty, Security Notwithstanding," in Charles Husband, ed., Social Cohesion, Securitization and Counter-Terrorism (Helsinki: Helsinki Collegium for Advanced Studies, 2012); Jeremy Waldron, "Security and Liberty: The Image of Balance," Journal of Political Philosophy 11 , no. 2 (2003).

${ }^{6}$ This history is detailed in Matthew J. Gibney, "'A Very Transcendental Power': Denaturalisation and the Liberalisation of Citizenship in the United Kingdom," Political Studies 61, no. 3 (2013), p. 641.

7 Audrey Macklin, "Kick-off Contribution" in Audrey Macklin and Rainer Baubock, eds., "The Return of Banishment: Do the New Denationalisation Policies Weaken Citizenship?" European University Institute Working Paper RSCAS 2015/14, http://cadmus.eui.eu/bitstream/handle/1814/34617/ RSCAS_2015_14.pdf?sequence=1, p. 2. 
${ }^{8}$ This is a simple rendering of a complex argument, which typically divides basic human rights that individuals possess simply in virtue of being human, and membership rights, which are those that individuals possess in virtue of being a member of a particular state. For a more precise account of the distinction, see Joseph H. Carens, The Ethics of Immigration (New York: Oxford University Press, 2013).

9 Ben Herzog, "Dual Citizenship and the Revocation of Citizenship," in Barbara Wejnert, ed., Democratic Paths and Trends (Bingley: Emerald Group Publishing, 2010), p. 88.

${ }^{10}$ Carens, The Ethics of Immigration, p. 101.

11 Ibid.

12 Gerard René de Groot, Maarten Vinc, and Iseult Honohan, "Loss of Citizenship: EUDO Citizenship Policy Brief No. 3" (European University Institute: European Union Democracy Observatory on Citizenship, 2010), p. 1.

${ }^{13}$ Cited in Betty de Hart and Ashley Terlouw, "Born Here. Revocation and the Automatic Loss of Dutch Nationality in Case of Terrorist Activities," in Marjolein Van den Brink et al., eds., Equality and Human Rights: Nothing but Trouble? (Utrecht: Utrecht University Netherlands Institute of Human Rights, 2014), p. 313 .

${ }^{14}$ It is, however, now being challenged in court, for being in violation of the Canadian Charter of Rights and Freedoms. See Michelle McQuigge, "Citizenship Law Bill C-24 Challenged as Unconstitutional by Civil Rights Groups,” Canadian Press, September 24, 2015, www.theglobeandmail.com/news/national/ citizenship-law-bill-c-24-challenged-as-unconstitutional-by-civil-rights-groups/article26032727/. It is also worth highlighting that the new Liberal government in Canada, elected in October 2015, has vowed to revoke the revocation law. No public progress has been made as of the writing of this article, however. See Ryan Maloney, "Bill C-24: Trudeau Says Terrorists Shouldn't Be Stripped Of Citizenship In Leaked Audio," Huffington Post Canada, September 28, 2015, www.huffingtonpost. ca/2015/o9/28/bill-c-24-trudeau-audio-conservatives_n_8206798.html.

15 Government of Canada, "The Government of Canada Introduces Protection of Canada from Terrorists Act," October 27, 2014, news.gc.ca/web/article-en.do?nid=897129.

${ }^{16}$ Unless the individual can somehow be shown to be voluntarily relinquishing her citizenship; that is, citizenship in the United States cannot be taken away from someone who doesn't voluntarily give it up. For more on the history of expelling citizens in the United States, see Patrick Weil, The Sovereign Citizen (Philadelphia: University of Pennsylvania Press, 2012).

17 Charlie Savage and Carl Hulse, "Bill Targets Citizenship of Terrorists' Allies," New York Times, May 6, 2010.

18 “Terrorists May Lose Norwegian Citizenship," Local, August 25, 2014, www.thelocal.no/20140825/norway-to-revoke-citizenship-of-terror-warriors-fighting-abroad.

19 Paul Farrell, "Citizenship Revocation Laws Likely to Pass after Labor Agrees to Amendments," Guardian, November 29, 2015, www.theguardian.com/australia-news/2015/nov/30/citizenshiprevocation-laws-likely-to-pass-after-labor-agrees-to-amendments.

20 "The Latest: Hollande Wants to Revoke French Citizenship of Convicted Terrorists," Associated Press, November 16, 2015, neurope.eu/wires/the-latest-hollande-wants-to-revoke-french-citizenship-ofconvicted-terrorists/.

${ }^{21}$ For more on the history of revocation in the United Kingdom, see Gibney, "A Very Transcendental Power."

${ }^{22}$ Ibid., p. 647.

${ }^{23}$ Ibid., p. 650 .

${ }^{24}$ Macklin, "Citizenship Revocation," p. 17.

${ }^{25}$ Guy Goodwin-Gill, "Deprivation of Citizenship Resulting in Statelessness and its Implications in International Law: Opinion.” Presented at an experts meeting, British House of Lords, 2014.

26 This is not a complete list, by any means. Moreover, not all states have provisions for the revocation.

${ }^{27}$ For a list of situations in which citizenship is revoked or understood to be renounced, see Groot, Vinc, and Honohan, "Loss of Citizenship."

${ }^{28}$ To be slightly more precise, revocation in cases of fraud may also be unjustified in some cases. In particular, it seems consistent with democratic values that citizenship granted based on fraud is subject to a statue of limitations, since after many years citizens whose status was obtained fraudulently may nevertheless possess a genuine link to the state in which they are a citizen. I will not defend that view, but see instead Rainer Bauböck and Vesco Paskalev, "Citizenship Deprivation: A Normative Analysis," in the Liberty and Security in Europe Papers (Brussels: Centre for European Policy Studies, 2015), pp. 1923.

29 Thomas Christiano, The Constitution of Equality: Democratic Authority and its Limits (New York: Oxford University Press, 2008), p. 12. 
30 Michael Saward, The Terms of Democracy (Cambridge: Polity Press, 1998).

${ }^{31}$ For an early and important articulation of this observation, see Iris Marion Young, Justice and the Politics of Difference (Princeton, N.J.: Princeton University Press, 1990).

${ }^{32}$ Groot, Vinc, and Honohan, "Loss of Citizenship."

${ }^{33}$ Matthew J. Gibney, "Should Citizenship Be Conditional? The Ethics of Denationalization," Journal of Politics 75, no. 3 (2013), p. 652.

34 Thomas Faist and Jürgen Gerdes, "Dual Citizenship in the Age of Mobility" (Washington, D.C.: Migration Policy Institute, 2008), p. 5.

35 Ibid., pp. 5-7.

${ }^{36}$ For an account of the trend toward sustaining connections among sending states and expatriates, see Rainer Bauböck, "Expansive Citizenship-Voting beyond Territory and Membership," Political Science \& Politics 38, no. 4 (2005). As a reviewer notes, the sending state is often more keen to permit the sustaining of formal ties than the receiving state.

37 Faist and Gerdes, "Dual Citizenship in the Age of Mobility," pp. 6-7.

${ }^{8}$ Savage and Hulse, "Bill Targets Citizenship of Terrorists' Allies." That said, in September 2014, Senate Democrats blocked a bill to revoke citizenship from Americans who join ISIS.

39 Forcese, "A Tale of Two Citizenships," p. 579.

40 Ibid., p. 583.

${ }^{41}$ The European Convention on Nationality acknowledges this in Article 5(2), "Each State Party shall be guided by the principle of non-discrimination between its nationals, whether they are nationals by birth or have acquired its nationality subsequently." See conventions.coe.int/Treaty/EN/Treaties/Html/166. htm. American laws, on the other hand, do permit some distinctions-for example, only citizens born on American soil are permitted to run for certain public offices, including both president and vicepresident.

${ }^{42}$ The range of alleged benefits conferred by dual citizenship is significant and beyond the scope of discussion here.

43 Benjamin Constant, "The Liberty of the Ancients Compared with that of the Moderns," in Biancamaria Fontana, ed., Benjamin Constant: Political Writings (Cambridge: Cambridge University Press, 1988 [originally published 1816]).

44 As written, this is a moral claim. That said, Canadian scholars are predicting that the revocation law as implemented will be subject to constitutional challenges. See, for example, Forcese, "A Tale of Two Citizenships."

45 Hart and Terlouw, "Born Here."

${ }^{46}$ The same argument applies to noncitizens who are deported after serving a criminal sentence.

47 I thank a reviewer for posing this objection to me, who put it thusly: "At least from a logical perspective, the punishment of revocation does fit the crime."

$4^{8}$ Gibney, "Should Citizenship Be Conditional?" p. 652.

49 Audrey Macklin, "Kick-Off Contribution," in Audrey Macklin and Rainer Bauböck, eds., The Return of Banishment: Do the New Denationalisation Policies Weaken Citizenship? (European University Institute: European Union Democracy Observatory on Citizenship, 2015).

${ }^{\circ}$ Chris Woods, "When Being Born British Isn't Enough," Bureau of Investigative Journalism, February 27, 2013.

${ }^{51}$ Michael Blake, "Distributive Justice, State Coercion, and Autonomy," Philosophy \& Public Affairs 30, no. 3 (2001).

52 Chris Alexander, speaking to the Canadian Parliament in defense of the new law, June 12, 2014, openparliament.ca/debates/2014/6/12/chris-alexander-14/only/.

53 Minister for Immigration and Border Protection, "Australian Citizenship Amendment (Allegiance to Australia) Bill 2015, Explanatory Memorandum,” parlinfo.aph.gov.au/parlInfo/download/legislation/ ems/r5507_ems_210d7d3c-aobf-4eao-9e7c-1bc3d4b48d5e/upload_pdf/EM\%20Citizenship\%20Allegiance \%20Bill\%20-\%2oamended.pdf;fileType=application\%2Fpdf2015. For discussion, see Neil James, “Terrorism, Treachery and Australian Citizenship," Strategist, June 23, 2015.

54 Hart and Terlouw, "Born Here," p. 316.

55 For example, see the debates between U.S. Supreme Court justices on the deterrence effects of capital punishment in Adam Liptak, "Supreme Court Allows Use of Execution Drug," New York Times, June 29, 2015. For a review of the literature on the deterrent effect of the death penalty in the United States, which suggests that no conclusion can be drawn from the research conducted in the past thirty years, see Daniel S. Nagin and John V. Pepper, Deterrence and the Death Penalty (Washington, D.C.: Committee on Deterrence and the Dealth Penalty, National Academies Press, 2012).

${ }^{56}$ As the authors of a 2014 report on the intentions of returning foreign fighters note (written prior to the Paris attacks), a recent attack on a synagogue in Brussels was committed by an individual who had been 
fighting in Syria. That said, the authors suggest that the danger posed by returning foreign fighters is likely exaggerated. See Daniel Byman and Jeremy Shapiro, "Be Afraid. Be a Little Afraid: The Threat of Terrorism from Western Foreign Fighters in Syria and Iraq," Policy Paper 34, Brookings Institute, 2014.

57 For example, see Jeanine de Roy van Zuijdewijn and Edwin Bakker, "Returning Western Foreign Fighters: The Case of Afghanistan, Bosnia and Somalia" (The Hague: International Centre for Counter-Terrorism, 2014). 